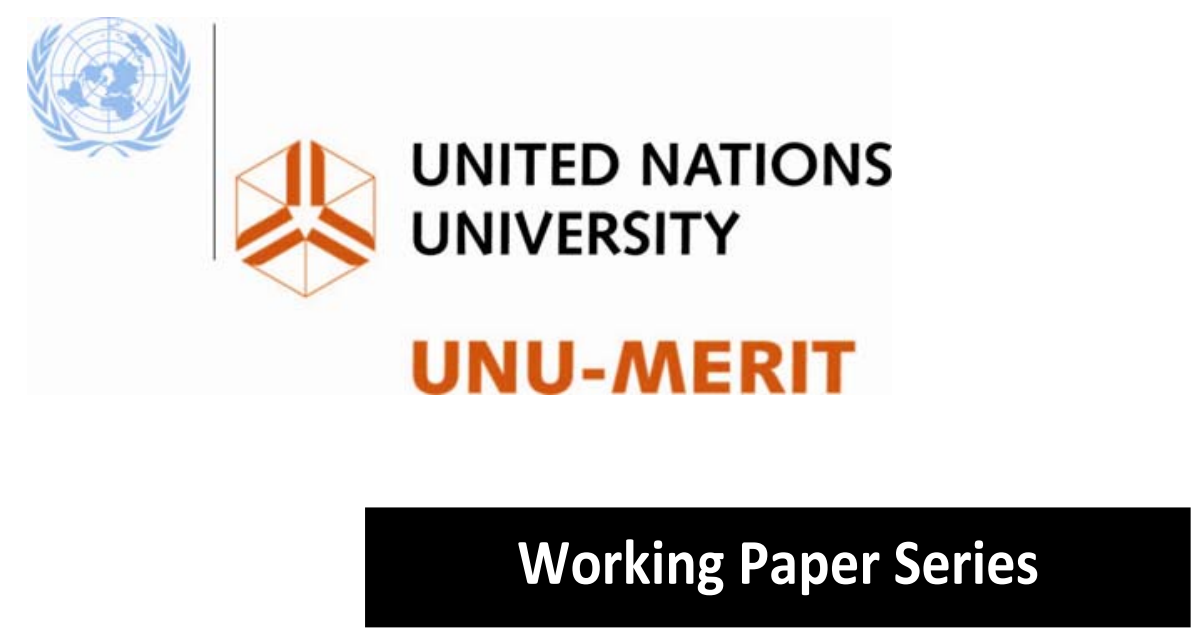

\#2013-047

Switching off or switching source: energy consumption and household response to higher energy prices in the Kyrgyz Republic

Franziska Gassmann and Raquel Tsukada

Maastricht Economic and social Research institute on Innovation and Technology (UNU-MERIT) email: info@merit.unu.edu | website: http://www.merit.unu.edu

Maastricht Graduate School of Governance (MGSoG)

email: info-governance@maastrichtuniversity.nl | website: http://mgsog.merit.unu.edu

Keizer Karelplein 19, 6211 TC Maastricht, The Netherlands

Tel: (31) (43) 388 4400, Fax: (31) (43) 3884499 


\section{UNU-MERIT Working Papers}

ISSN 1871-9872

Maastricht Economic and social Research Institute on Innovation and Technology, UNU-MERIT

Maastricht Graduate School of Governance

MGSoG

UNU-MERIT Working Papers intend to disseminate preliminary results of research carried out at UNU-MERIT and MGSoG to stimulate discussion on the issues raised. 


\title{
Switching off or switching source: energy consumption and household response to higher energy prices in the Kyrgyz Republic*
}

\author{
Franziska Gassmann $^{\dagger} \quad$ Raquel Tsukada ${ }^{\ddagger}$
}

October 8, 2013

\begin{abstract}
"Access to energy is fundamental to improving quality of life and is a key imperative for economic development" (Energy Poverty Action). This is particularly true in Central Asia where winters are harsh and long. Changes in energy prices affect the purchasing power of households, hitting the poor in particular. The impact very much depends on a household's energy basket and the available strategies for switching to alternative energy sources. Using data from the Kyrgyz Integrated Household Survey (KIHS) 2011, this paper analyzes the profile of household energy consumption and the impact of electricity tariff increases on the probability that households would switch to alternative energy sources. Results suggest that households would respond to an electricity price increase by increasing consumption of fuels: households would tend to move away from electricity-only heating source towards the use of stove-only.
\end{abstract}

JEL classification: H23, I38, P22

Keywords: energy; household consumption; Central Asia; Kyrgyz Republic.

\section{Introduction}

Several countries in Central Asia have been advised to reform the energy sector. In its 2011 report on Central Asia, the International Crisis Group (ICG) recommended the Central Asian governments to "open the sector to market reforms by significantly decreasing state control and encouraging competition and external investment. Develop a timeline for bringing tariffs in line with market prices and design a targeted system of assistance for socially vulnerable populations" (ICG, 2011, p.ii). A central component in such reforms is bringing electricity tariffs up to the cost recovery level. This is necessary for sustainable service provision and in order to enable infrastructure investments required in the sector.

${ }^{*}$ The authors gratefully acknowledge the support of the Kyrgyz National Statistics Committee in giving access to the household survey data. We also thank Jeanne Féaux de la Croix and Dave Gullette for their valuable comments and suggestions.

${ }^{\dagger}$ United Nations University - Maastricht Economic and Social Research Institute on Innovation and Technology, and Maastricht Graduate School of Governance (UNU-MERIT/MGSoG). E-mail: franziska.gassmann@maastrichtuniversity.nl

${ }^{\ddagger}$ UNU-MERIT. Email: tsukada@merit.unu.edu 
The general prediction of a price increase according to microeconomic theory is a decrease in demand due to income and substitution effects. The response of consumers to an electricity tariff increase would be reducing energy consumption (an allusion to 'switching off', as suggested in the title) as their purchasing power is reduced. According to the Energy Poverty Action Initiative of the World Economic Forum, "access to energy is fundamental to improving quality of life and is a key imperative for economic development" (EPA). Hence reducing energy consumption below a certain minimum may hinder development. Consumers could also consider switching to alternative energy sources, when substitutes are available. Switching to alternative sources may however not always be desirable. Adopting alternative energy sources may not be physically or financially possible, particularly in the short term. Moreover, the alternative source could have undesirable side effects such as health problems caused by indoor air pollution (see Duflo et al., 2008, and Akhmetov, 2013), therefore reducing the household's wellbeing. Neither is it desirable that households would climb down the energy ladder, i.e. downgrading from the use of efficient energy sources (electricity or modern fuels) to the use of biomass fuels (firewood, dung, crop residues etc.) (UNDP, 2000). Understanding the consumption behavior of households and constraints to their possible coping strategies is essential when designing energy policies such as a tariff increase.

The Kyrgyz Republic is no exception among the former Soviet Union countries when it comes to heavily subsidized energy tariffs and repeated reform attempts over the past two decades. After the collapse of the Soviet system the energy infrastructure deteriorated dramatically and countries were confronted with higher energy prices. Towards the end of the 1990s, several countries in the region started reforming the energy sector and raised tariffs in order to make the sector financially viable and encourage efficient energy consumption. In 2003 though, electricity tariffs were still below cost-recovery level in 14 out of 19 countries in Eastern Europe and Central Asia (Lampietti et al., 2007).

Reforming the energy sector has been on the Kyrgyz government's agenda since as early as 1995 . Over the years, the government has simplified the structure and increased the tariffs several times. After having raised electricity tariffs five times between 1999 and 2002 (USAID, 2008), the number of tariff blocks was reduced from six to two in March 2003. Between 2003 and 2006, the tariffs remained unchanged. In May 2006, a unified tariff was introduced at KGS 0.62 per $\mathrm{kWh}$, which was increased to KGS 0.7 per $\mathrm{kWh}$ in 2008. In 2008, the government also adopted a mid-term strategy for electricity tariffs with the objective of achieving cost-recovery level in 2012. Besides the objectives related to the production and delivery of electricity, the strategy also determined that by 2012 all electricity subsidies must be targeted to the low-income consumers and provided through the state social benefit system (USAID, 2008, p.52). The latest reform attempt dates back to January 2010, when electricity tariffs doubled and thermal power prices quadrupled. The aim of this substantial increase was to eliminate implicit universal subsidies and to introduce equitable cost-recovery tariffs. However, after the political unrest in April 2010, which was also an expression of the population's dissatisfaction with the tariff reform and eventually led to the outing of President Bakiyev, the government was forced to undo the increase in residential energy tariffs. Currently, electricity tariffs are still at a level below full cost recovery. USAID (2011) estimated the full cost recovery price for electricity at KGS 2.03 per kWh (USD 0.044), implying a subsidy of KGS 1.33 per $\mathrm{kWh}$ given the current tariff of KGS 0.7 per $\mathrm{kWh}$. It is estimated that implicit energy subsidies accounted for more than 4 percent of GDP in 2009 (Gassmann, 2013). 
Access to reliable and affordable energy is essential for a country like the Kyrgyz Republic, where winters are long and cold. The country is landlocked and its climate is influenced by the Tien Shan and Pamir mountain ranges, which dominate the country. However, regions vary considerably in terms of climate. The South-Western part in the Ferghana Valley has a subtropical climate with very hot summers. The climate to the North of the mountains is temperate, while the areas high in the Tien Shan Mountains are characterized by a dry continental and even polar climate. It is not unusual that temperatures in these locations stay below zero for more than 40 days in the winter. Generating sufficient warmth is vitally important for survival.

This paper investigates the potential impact of electricity price increases on residential energy consumption in the Kyrgyz Republic. First, we analyze the energy consumption profile of households. Given that a great share of energy is used for space heating, we then investigate the determinants of households' choice of energy for heating, and analyze the probability that households would switch to alternative sources ${ }^{1}$ as a response to electricity price increases. ${ }^{2}$

The data used for the analysis in this paper stem from the 2011 Kyrgyz Integrated Household Survey (KIHS). The KIHS is an annual survey implemented by the National Statistical Committee of the Kyrgyz Republic. The sample covers about 5,000 households, representative at the national and regional levels. The survey collects detailed information on household demographics, including education, health, migration, individual employment, housing, land and livestock possession, and household incomes and expenditures.

The impact of energy reforms in Eastern European and Central Asian countries has been increasingly studied. One strand of the literature is concerned with the distributional impacts and policies to mitigate the negative impact on the poor. Studies of electricity price increases in Poland (Freund and Wallich, 1997), electricity and thermal energy in the Kyrgyz Republic (Gassmann, 2013), and gas in Armenia (Ersado, 2012) find a disproportionally higher negative impact on the poorest households. To mitigate that effect, Price and Pham (2009) recommend always including lifeline tariffs at any tariff scheme, after analyzing hypothetical scenarios of electricity reform in Albania and Bulgaria. Gassmann (2013) also analyzes the effect of reducing subsidies, including lifeline tariffs and she proposes introducing cash transfers to compensate the poorest households in the Kyrgyz Republic.

This paper adds to another strand of literature on impact of energy reforms, which investigates household energy choices and household behavioral response to energy price increases. A key question in this literature is when households would consider switching to alternative energy sources. Our paper investigates the determinants of energy choice in the Kyrgyz Republic with focus on energy for heating space, which accounts for a large

\footnotetext{
${ }^{1}$ In this paper alternative energy sources refer to energy sources for space heating currently used by households, such as electricity, gas, firewood, coal, dung or other fuels.

${ }^{2}$ As a reaction to higher energy prices, households could alternatively: (i) maintain their current consumption at the cost of a substantially higher energy bill, (ii) reduce their energy consumption to the extent that the bill remains unchanged, (iii) switch to cheaper energy sources, such as to maintain energy expenditure unchanged, or (iv) they could even divert to energy theft or the incurrence of payment arrears. This later case is not taken into account in our analysis, as it is not possible to identify from the survey when households adopt such strategy.
} 
share of residential energy consumption in Central Asian countries. Previous studies have focused on cooking fuels (Heltberg, 2004, 2005). Our paper also contributes to understanding the determinants and limitations of households in switching to different heating energy sources. It adds to the literature by bringing evidence for the Kyrgyz Republic, in line with Silva et al. (2009) who have simulated the response of households in Montenegro to electricity tariff increases.

\section{Energy consumption in the Kyrgyz Republic}

Changes in energy prices affect the purchasing power of households. The effect depends on the magnitude of the price change, a household's energy basket, and its available strategies for switching to alternative energy sources. Studies on the potential removal of electricity subsidies estimate the expected real income loss to range between 2 and 16 percent for the poorest 20 percent of the population (IEA, OPEC, OECD, World Bank, 2010, Annex 4; Adenauer and del Granado, 2011). Estimates for the Kyrgyz Republic indicate in general a real welfare loss of 5 percent for the poorest households if electricity tariffs would be raised to cost recovery levels (Gassmann, 2013). Both the composition of the energy used and available switching strategies depend on the household's location, welfare level and demographic composition. It is therefore essential to know the energy consumption basket for different households.

\subsection{Household energy consumption profile}

The first question in reforming energy tariffs must be what are the most common energy sources used by households. Access to electricity is close to universal in the Kyrgyz Republic (see Table 1), although service provision may not always be reliable. ${ }^{3}$ The second most commonly used energy source is solid fuel, used by over 60 per cent of households. ${ }^{4}$ Since the use of multiple energy sources is rather common in the Kyrgyz Republic, an electricity tariff increase would probably have no linear effect on consumption because households would likely rebalance their energy basket by mixing several sources. After all, they have already adopted that strategy. Irrespective of the location, households rely on more than one energy source, as we see in Table 1.

An assessment of energy sources by location reveals significantly different profiles of energy use. Provision of (district) central heating and piped gas is concentrated in flat areas, reinforcing the idea that natural barriers still hinder service delivery in other terrains in the Kyrgyz Republic. These services are heavily concentrated in the country's capital. Bishkek stands out in the use of central heating and piped gas, followed by a few users scattered in other urban areas across the country. Despite wide availability of electricity, the incidence of households using of fuels is very high. Above 50 per cent of households, even among the richest in the nation (see upper quintiles of the income distribution), rely

\footnotetext{
${ }^{3}$ Electricity provision is especially unreliable during the winter and affects the whole country. For example, during the cold December 2012, Bishkek had more than 900 power outages per week (http://www.eurasianet.org/node/66309, accessed on 17 December 2012). In 2011, 10.4 per cent of households reported weekly power interruptions. Moreover, many rural residents, e.g. in Naryn, migrate to high pastures in the summer where electricity provision is either totally absent or precarious.

${ }^{4}$ In the KIHS, fuel refers to firewood, brushwood, black coal, peat, pressed dung, corn brans, kerosene, diesel, black oil and bottle gas.
} 
on fuel.

Table 1: Share of households with positive expenditures on energy sources (in \%)

\begin{tabular}{lrrrr}
\hline \hline & Electricity & Central heating & Piped gas & Fuels \\
\hline Total & 99.7 & 15.7 & 26.7 & 60.5 \\
& & & & \\
High mountain areas & 99.8 & 0.9 & 1.0 & 81.9 \\
Semi mountain areas & 100.0 & 1.8 & 1.5 & 59.6 \\
Flat areas & 99.6 & 19.9 & 34.3 & 57.9 \\
& & & & \\
Bishkek & 98.7 & 57.1 & 76.5 & 15.5 \\
Other urban areas & 99.9 & 15.2 & 34.5 & 54.4 \\
Rural areas & 99.9 & 2.3 & 7.3 & 77.5 \\
& & & & \\
Issyk Kul & 99.9 & 2.8 & 0.3 & 58.2 \\
Jalalabad & 100.0 & 3.8 & 14.8 & 65.4 \\
Naryn & 99.5 & 2.0 & 0.4 & 78.2 \\
Batken & 99.8 & 2.2 & 12.7 & 85.1 \\
Osh & 100.0 & 5.5 & 20.3 & 80.4 \\
Talas & 100.0 & 0.8 & 0.6 & 63.7 \\
Chui & 100.0 & 14.1 & 23.1 & 64.3 \\
Bishkek & 98.7 & 57.1 & 76.5 & 15.5 \\
& & & & \\
Quintile I & 99.8 & 5.6 & 16.0 & 67.3 \\
Quintile II & 99.8 & 6.0 & 16.2 & 69.3 \\
Quintile III & 99.9 & 14.2 & 24.0 & 61.2 \\
Quintile IV & 99.4 & 20.4 & 32.1 & 58.1 \\
Quintile V & 99.5 & 32.2 & 45.1 & 46.4 \\
\hline \hline
\end{tabular}

Source: KIHS (2011). Note: Since households may use multiple energy sources, shares do not add up to 100 percent. Quintiles at household level, based on total household expenditures per capita. Note that only few areas in the Kyrgyz Republic are provided with central heating (Bishkek and parts of Chui Valley, Naryn Town, Osh City and a few other places).

Solid fuels are fundamentally important alternative sources to electricity in the Kyrgyz Republic. The basket composition of fuel consumption varies considerably across the geographical locations. Firewood and coal are equally the most prevalent fuels used for heating or cooking purposes with the exception of Bishkek (see Table 2). Between 2007 and 2010 the consumption of coal increased to almost 60 per cent (Slay, 2011, p.16), although it can effectively be used only in detached homes. It is also interesting that corn is especially prevalent in the southern regions (Jalalabad and Osh - the Ferghana valley is very fertile and used for agriculture and crops). Dung on the other hand is very popular in Naryn, a very mountainous regions with lots of livestock.

The preference of households for either firewood or coal does not differ sharply according to income distribution (see lower panel in Table 2). Apart from the richest quintile, the proportion of households using one or another fuel remains balanced within the same income quintile. As the energy ladder theory foresees, it is clear that as households become wealthier the incidence of non-modern fuel use tends to decrease.

Energy security requires uninterrupted availability of energy, at an affordable price (In- 
Table 2: Share of households using solid fuel for heating or cooking (in \%)

\begin{tabular}{lrrrr}
\hline \hline & Wood & Coal & Dung/peat & Corn \\
\hline Total & 65.8 & 65.6 & 31.3 & 12.6 \\
& & & & \\
High mountain areas & 81.3 & 86.5 & 66.6 & 1.9 \\
Semi mountain areas & 87.9 & 64.6 & 53.4 & 24.9 \\
Flat areas & 60.0 & 63.1 & 23.1 & 11.7 \\
& & & & \\
Bishkek & 7.6 & 17.4 & 0.2 & 0.0 \\
Other urban areas & 55.0 & 57.4 & 9.7 & 5.8 \\
Rural areas & 89.1 & 84.6 & 49.9 & 19.3 \\
& & & & \\
Issyk Kul & 84.9 & 59.8 & 37.7 & 0.2 \\
Jalalabad & 76.0 & 70.3 & 35.1 & 20.0 \\
Naryn & 62.0 & 85.4 & 83.9 & 0.1 \\
Batken & 90.9 & 90.0 & 44.3 & 7.1 \\
Osh & 84.4 & 84.7 & 48.8 & 35.3 \\
Talas & 68.7 & 70.7 & 38.1 & 0.0 \\
Chui & 75.5 & 75.7 & 14.4 & 1.3 \\
Bishkek & 7.6 & 17.4 & 0.2 & 0.0 \\
Quintile I & & & & \\
Quintile II & 77.1 & 73.4 & 39.6 & 16.0 \\
Quintile III & 73.0 & 73.7 & 37.9 & 16.7 \\
Quintile IV & 69.9 & 71.1 & 29.3 & 13.1 \\
Quintile V & 61.1 & 61.1 & 28.3 & 9.8 \\
\hline \hline
\end{tabular}

Source: KIHS (2011). Note: Since households may use multiple energy sources, shares do not add up to 100 percent. Quintiles at household level, based on total household expenditures per capita.

ternational Energy Agency). Household energy expenditure by type of energy shows that overall the largest share of the total household expenditure is spent on solid fuels (KGS 3,957 , approximately USD 85.12), followed by electricity (KGS 2,737, approximately USD 58.88). ${ }^{5}$ This certainly varies with the households' actual energy consumption basket, and thus Table 3 cannot provide either availability or affordability information for assessing household energy security in Kyrgyzstan. However, given that the electricity price is fixed across the country at a single tariff (KGS 0.7 per kWh in the survey period), Table 3 can shed light on "across location" comparisons of the actual quantity (kWh) of electricity consumption of households. It varies on average between the lowest expenditure, thus quantity consumed, in Batken (KGS 2,423, approximately USD 52.12) to the highest average consumption in Chui (KGS 3,093, approximately USD 66.54). Bishkek once again stands out, having a different pattern than the other regions. Its average expenditure for thermal power is substantially higher than the expenditure in any other energy sources.

Total expenditure by geographical location indicates the existence of large inequalities in energy expenditure within the Kyrgyz Republic. The average household in Bishkek spends about 36 per cent more on energy than an average household in other urban areas, 41 per cent more than its rural counterparts, and as much as 91 per cent more than an average household living in Issyk Kul. These differences in energy consumption are

\footnotetext{
${ }^{5}$ Exchange rate as per 31 December 2011: 46.4847 KGS/USD. Source: National Bank of the Kyrgyz Republic, available at http://www.nbkr.kg, (accessed on 25 September 2013).
} 
partly related to overall living standards in the various regions. Bishkek and Chui are the most affluent regions with the lowest poverty rates, while the highest poverty rates are observed in Issyk Kul, Naryn and Talas (World Bank, 2011). It is true, however, that Table 3 cannot show us the actual energy wellbeing enjoyed by each of these groups, as this could only be assessed by an estimate of the total kWh quantity of energy consumed by households, adding up all energy sources.

Table 3: Annual household expenditures by type of energy (in KGS) and share in total household expenditure

\begin{tabular}{|c|c|c|c|c|c|c|c|c|c|c|}
\hline & \multicolumn{5}{|c|}{ Annual energy expenditure } & \multicolumn{5}{|c|}{ Share of energy in total expenditure } \\
\hline & Electricity & $\begin{array}{r}\text { Thermal } \\
\text { power }\end{array}$ & $\begin{array}{r}\text { Piped } \\
\text { gas }\end{array}$ & Fuels & $\begin{array}{l}\text { Total energy } \\
\text { expenditures }\end{array}$ & Electricity & $\begin{array}{r}\text { Thermal } \\
\text { power }\end{array}$ & $\begin{array}{r}\text { Piped } \\
\text { gas }\end{array}$ & Fuels & Total \\
\hline Total & 2,737 & 947 & 1,024 & 3,957 & 8,665 & 2.19 & 0.75 & 0.78 & 2.80 & 6.52 \\
\hline High mountain areas & 2,521 & 49 & 6 & 4,986 & 7,563 & 2.03 & 0.03 & 0.01 & 3.81 & 5.88 \\
\hline Semi mountain areas & 2,960 & 97 & 15 & 2,564 & 5,636 & 2.43 & 0.08 & 0.01 & 1.88 & 4.41 \\
\hline Flat areas & 2,725 & 1,206 & 1,326 & 4,070 & 9,328 & 2.16 & 0.96 & 1.01 & 2.83 & 6.97 \\
\hline Bishkek & 2,819 & 3,915 & 3,430 & 1,072 & 11,236 & 2.14 & 3.18 & 2.50 & 0.74 & 8.55 \\
\hline Other urban areas & 2,935 & 592 & 983 & 3,727 & 8,238 & 2.46 & 0.47 & 0.86 & 2.72 & 6.50 \\
\hline Rural areas & 2,633 & 111 & 252 & 4,993 & 7,989 & 2.10 & 0.07 & 0.19 & 3.51 & 5.86 \\
\hline Issyk Kul & 2,906 & 90 & 3 & 2,895 & 5,895 & 2.50 & 0.07 & 0.00 & 2.11 & 4.68 \\
\hline Jalalabad & 2,707 & 50 & 471 & 3,119 & 6,347 & 2.14 & 0.03 & 0.37 & 2.24 & 4.78 \\
\hline Naryn & 3,025 & 114 & 2 & 4,317 & 7,458 & 2.29 & 0.07 & 0.00 & 3.01 & 5.37 \\
\hline Batken & 2,423 & 20 & 338 & 5,522 & 8,302 & 1.52 & 0.01 & 0.30 & 3.24 & 5.07 \\
\hline Osh & 2,307 & 149 & 490 & 5,726 & 8,671 & 1.88 & 0.12 & 0.41 & 4.07 & 6.49 \\
\hline Talas & 3,482 & 25 & 3 & 3,194 & 6,703 & 2.69 & 0.02 & 0.00 & 2.19 & 4.90 \\
\hline Chui & 3,093 & 865 & 911 & 5,658 & 10,527 & 2.71 & 0.63 & 0.75 & 4.24 & 8.33 \\
\hline Bishkek & 2,819 & 3,915 & 3,430 & 1,072 & 11,236 & 2.14 & 3.18 & 2.50 & 0.74 & 8.55 \\
\hline Quintile I & 2,591 & 237 & 439 & 3,469 & 6,735 & 2.47 & 0.23 & 0.44 & 2.98 & 6.11 \\
\hline Quintile II & 2,803 & 366 & 588 & 4,582 & 8,339 & 2.32 & 0.31 & 0.48 & 3.39 & 6.51 \\
\hline Quintile III & 2,859 & 711 & 1,000 & 4,051 & 8,621 & 2.29 & 0.66 & 0.82 & 2.78 & 6.55 \\
\hline Quintile IV & 2,642 & 1,230 & 1,332 & 3,846 & 9,050 & 1.95 & 0.95 & 0.95 & 2.43 & 6.28 \\
\hline Quintile V & 2,792 & 2,189 & 1,764 & 3,838 & 10,583 & 1.90 & 1.61 & 1.22 & 2.43 & 7.15 \\
\hline
\end{tabular}

Source: KIHS (2011). Quintiles at household level, based on total household expenditures per capita.

The share of energy expenditure in the total household expenditure provides some insight regarding affordability. Overall, households spend about 6.5 per cent of their total expenditure on energy consumption (see Table 3, right panel). Energy consumption shows signs of inequality in affordability are most pronounced across regions (oblasts). While in Talas a household spends on average 4.9 per cent of its total expenditures on energy, in Bishkek households spend larger proportion of resources, about 8.6 per cent of their total expenditures. The share of energy expenditure on the household budget does not vary much across income quintiles. It is about 6.1 per cent in the poorest quintile and about 7.2 per cent if total expenditure of households in the highest quintile of the income distribution. This however must be interpreted with caution, since it could be the case that households in Batken have lower expenditure simply because there is less service provision and households are therefore constrained in consumption.

Given the long, cold winters in the Kyrgyz Republic, space heating takes an important share of households' energy consumption. Three main space heating technologies are found in the Kyrgyz Republic: central (or district) heating is used by 15.8 per cent of households, electric heating by 37.1 per cent, and stove heating is the most common heating source, adopted by 74.7 per cent of households (see Table 4). Households may 
also use a combination of different sources, for example electricity and stove heating, and therefore the columns in Table 4 do not add up to 100 per cent.

Table 4: Heating source: share of households using each source (in \%)

\begin{tabular}{|c|c|c|c|c|}
\hline & $\begin{array}{l}\text { Central } \\
\text { heating }\end{array}$ & $\begin{array}{l}\text { Electric } \\
\text { heating }\end{array}$ & Stove & Other \\
\hline Total & 15.8 & 37.1 & 74.7 & 7.0 \\
\hline High mountain areas & 0.9 & 34.3 & 97.5 & 0.0 \\
\hline Semi mountain areas & 2.4 & 46.8 & 92.1 & 0.2 \\
\hline Flat areas & 20.0 & 35.7 & 68.4 & 9.1 \\
\hline Bishkek & 60.4 & 19.7 & 21.5 & 18.0 \\
\hline Other urban areas & 15.8 & 53.5 & 64.3 & 8.0 \\
\hline Rural areas & 1.2 & 36.3 & 95.6 & 3.1 \\
\hline Issyk Kul & 3.9 & 33.5 & 91.9 & 0.0 \\
\hline Jalalabad & 2.9 & 55.2 & 84.9 & 5.7 \\
\hline Naryn & 2.0 & 43.1 & 95.2 & 0.0 \\
\hline Batken & 0.2 & 30.6 & 91.4 & 8.8 \\
\hline Osh & 5.7 & 42.4 & 87.3 & 5.0 \\
\hline Talas & 0.9 & 45.9 & 93.7 & 1.2 \\
\hline Chui & 12.1 & 31.4 & 79.9 & 4.7 \\
\hline Bishkek & 60.4 & 19.7 & 21.5 & 18.0 \\
\hline Quintile I & 5.5 & 34.9 & 86.6 & 5.7 \\
\hline Quintile II & 6.9 & 41.6 & 85.3 & 5.1 \\
\hline Quintile III & 12.2 & 35.9 & 77.4 & 7.6 \\
\hline Quintile IV & 20.4 & 37.7 & 69.8 & 7.1 \\
\hline Quintile V & 34.1 & 35.2 & 52.7 & 9.7 \\
\hline Hh lives in separte house & 0.4 & 37.5 & 92.0 & 8.1 \\
\hline
\end{tabular}

Source: KIHS (2011). Quintiles at household level, based on total household expenditures per capita. Other includes gas or other sources.

On classifying households according to the main heating source, the following categories are recognizable: 5.1 per cent of households use only electricity as heating source, 12.5 per cent use only central heating (though this service is concentrated in Bishkek and parts of Chui Valley), and almost half of Kyrgyz households only use stoves (45.7 per cent). The most frequent combination of heating sources is electricity plus stove, a strategy adopted by 26.4 per cent of households. Table 5 conveys two important messages. First, a majority of households rely on a single energy source for heating. Switching to a different technology, or enlarging its energy portfolio for space heating, may imply certain cost. The second message is the importance of fuels on the livelihood of households in the Kyrgyz Republic. Table 5 shows that stoves are by far the most frequent technology adopted by households in the Kyrgyz Republic. The incidence of stove-only heating is above 50 per cent of households in all regions except Bishkek and Jalalabad oblast. It is as high as 65.6 per cent of households in Issyk Kul oblast. 
Table 5: Share of households by main heating source (in \%)

\begin{tabular}{|c|c|c|c|c|c|}
\hline & $\begin{array}{r}\text { Electricity } \\
\text { only }\end{array}$ & $\begin{array}{r}\text { Central } \\
\text { heat only }\end{array}$ & $\begin{array}{r}\text { Stove } \\
\text { only }\end{array}$ & $\begin{array}{l}\text { Electricity } \\
\text { and stove }\end{array}$ & $\begin{array}{l}\text { Other } \\
\text { combo }\end{array}$ \\
\hline Total & 5.1 & 12.5 & 45.7 & 26.4 & 10.3 \\
\hline High mountain areas & 1.6 & 0.4 & 65.3 & 32.2 & 0.4 \\
\hline Semi mountain areas & 5.3 & 1.1 & 52.0 & 40.2 & 1.5 \\
\hline Flat areas & 5.6 & 16.0 & 42.1 & 23.3 & 13.1 \\
\hline Bishkek & 2.6 & 53.2 & 12.5 & 6.6 & 25.0 \\
\hline Other urban areas & 15.5 & 8.4 & 33.0 & 27.8 & 15.3 \\
\hline Rural areas & 1.9 & 0.8 & 61.5 & 32.3 & 3.5 \\
\hline Issyk Kul & 4.2 & 0.8 & 65.6 & 26.3 & 3.0 \\
\hline Jalalabad & 8.2 & 1.4 & 40.1 & 43.3 & 7.1 \\
\hline Naryn & 2.8 & 1.0 & 55.9 & 39.3 & 1.0 \\
\hline Batken & 4.7 & 0.2 & 63.7 & 22.7 & 8.8 \\
\hline Osh & 6.2 & 1.6 & 53.0 & 30.1 & 9.2 \\
\hline Talas & 4.2 & 0.3 & 52.8 & 40.9 & 1.8 \\
\hline Chui & 4.9 & 9.8 & 57.2 & 21.0 & 7.0 \\
\hline Bishkek & 2.6 & 53.2 & 12.5 & 6.6 & 25.0 \\
\hline Quintile I & 5.8 & 4.0 & 57.7 & 25.5 & 6.9 \\
\hline Quintile II & 4.3 & 5.0 & 50.0 & 33.7 & 7.0 \\
\hline Quintile III & 4.1 & 10.5 & 48.7 & 27.5 & 9.3 \\
\hline Quintile IV & 5.6 & 15.8 & 41.4 & 25.5 & 11.7 \\
\hline Quintile V & 5.9 & 27.2 & 30.5 & 19.8 & 16.6 \\
\hline Hh lives in separate house & 2.2 & 0.2 & 56.7 & 32.6 & 8.3 \\
\hline
\end{tabular}

Source: KIHS (2011). Quintiles at household level, based on total household expenditures per capita.

\subsection{The ability to switch to alternative energy sources}

When prices of a particular energy source increase, the poorest households relying on that source are likely to be hit the hardest. This general statement may however not always be true. The ability to switch to alternative energy sources at a low investment cost may partially mitigate the monetary loss caused by the introduction of the tariff. Some alternative technologies, however, are still unaffordable for most households, as is the case with most renewable energy sources such as solar panels, wind energy or small scale hydropower units. In this sense, households living in dwellings which are unable to switch to alternative energy sources may be hit strongly, even if these are not at the bottom percentiles of population. The ability to switch to alternative energy sources in the Kyrgyz Republic depends to a large extent on the location of households: better service provision is often concentrated in areas with easier geographical access and critical demand density, such as Bishkek and a few urban centers.

Central gas supply, hot water and central heating are not available or are scarcely provided at high altitudes, semi-mountainous or rural areas. For that reason, we next turn to the analysis of the household space heating choice, focusing on choices of electricity or stoves/furnace, as these represent real opportunities of alternative heating sources to all 
Table 6: Share of households with (operational) modern energy source (in \%)

\begin{tabular}{|c|c|c|c|c|c|c|c|c|c|c|}
\hline & Total & $\begin{array}{r}\text { High } \\
\text { mountain }\end{array}$ & $\begin{array}{r}\text { Semi } \\
\text { mountain }\end{array}$ & $\begin{array}{l}\text { Flat } \\
\text { areas }\end{array}$ & Bishkek & $\begin{array}{l}\text { Other } \\
\text { urban }\end{array}$ & Rural & Not poor & Poor & $\begin{array}{r}\text { Extremely } \\
\text { poor }\end{array}$ \\
\hline Electricity & 99.86 & 99.92 & 99.98 & 99.83 & 99.8 & 99.9 & 99.87 & 99.84 & 99.97 & 99.58 \\
\hline Central gas supply & 24.91 & 0 & 0 & 32.33 & 73.8 & 32.48 & 5.93 & 29.41 & 12.67 & 11.34 \\
\hline Hot water & 14.22 & 0 & 1.74 & 18.15 & 58.81 & 9.6 & 1.4 & 17.77 & 4.79 & 1.49 \\
\hline Central heating & 16.63 & 0.99 & 3.47 & 20.85 & 60.74 & 16.98 & 2.03 & 20.55 & 5.65 & 7.76 \\
\hline
\end{tabular}

Source: Authors' calculations based on KIHS 2011. Individual level weights. Except for electricity, differences across groups are statistically significant $(p<0.01)$.

households.

\section{The Household Energy Choice}

In this section, we investigate the determinants of a household's choice of a particular energy source. Here we focus on space heating, as that represents an important final use of energy for households in the Kyrgyz Republic, considering the harsh climate with long and cold winters. Using a multinomial outcome model ${ }^{6}$ we estimate the determinants of the household choice of heating source based on socio-demographic characteristics and environmental conditions of the household. The model also allows investigating the importance of energy prices in determining the probability of households considering a switch to alternative energy sources.

\subsection{Model specification}

Households in the Kyrgyz Republic can choose between electricity, central heating, piped gas, stove/furnace, and any combination of these sources for space heating. To perform a realistic analysis we need to restrict the sample to households that could feasibly switch to another heating source. Therefore, we cannot include in this part of the analysis households using central heating, piped gas or any combination involving those. The reason is that these households, as argued before, are rather limited in their ability to disconnect from such heating sources - as households not connected to them may also have little opportunity to start using them. For instance, once connected to central district heating the household is not able to physically disconnect from it. Also a household may be only able to connect to the system if district heating is already available at its location and even at its building. As Table 5 shows, according to the Kyrgyz Integrated Household Survey 2011, at least 72.1 per cent of households rely on fuel (stoves) for space heating (45.7 exclusively using stove and 26.4 per cent using stove and electricity). Hence, the restricted sample for this analysis consists of 3,788 households: 6.7 per cent use electricity only, 34 per cent use stove only, and 59 per cent use a combination of electricity and stove (Table 7). Despite using electricity-only for heating, about 18 per cent of households purchased or consumed firewood and 18 per cent of households purchased or consumed coal throughout the survey year. Among households using stove-only sources, about 87.5 per cent acquired firewood and 87 per cent coal, denoting that firewood and coal have much higher prevalence than dung/peat or corn.

\footnotetext{
${ }^{6}$ Multinomial logit model is a discrete choice model in which the outcome variable consists of a set of several possible alternatives and the outcomes carry no ordering.
} 
Table 7: Share of households using either electricity and/or stove, and share of households by purchase or consumption of four major solid fuels

\begin{tabular}{lc|rrrr}
\hline \hline & \% of & \multicolumn{4}{|c}{ Solid fuel consumption: } \\
& households & Wood & Coal & Dung/peat & Corn \\
\hline Electricity only & 6.7 & 17.9 & 18.0 & 4.7 & 1.9 \\
Electricity and stove & 34.2 & 84.4 & 83.8 & 33.1 & 16.4 \\
Stove only & 59.2 & 87.5 & 86.9 & 48.7 & 16.6 \\
\hline \hline
\end{tabular}

Note: Restricted sample. Excludes households using central heating, other sources and other combinations. All households use electricity as this is used for other purposes than heating as well.

The model estimates the relative probability of households choosing alternative heating sources. The dependent variable is the three-category household space heating energy source: (i) electricity only, (ii) solid fuel only, and (iii) combination of electricity and fossil fuel.

The particular interest of this paper is in the effect of higher electricity prices on the household choice of heating source. Since the price of electricity is fixed across the entire country (at KGS 0.70 per kWh), we use the relative prices (per kWh) of electricity to the major fossil fuels used by households (firewood and coal) ${ }^{7}$ as key explanatory variables. Solid fuel prices vary significantly across regions. Based on household-declared fuel consumption and expenditure in KIHS 2011, we estimated the average price of each fuel per oblast and area (urban/rural $)^{8}$. Fifteen different average prices for each fuel are obtained. The nominal prices were converted into price per $\mathrm{kWh}$, and the ratio of the price of electricity to the price of the fuel per $\mathrm{kWh}$ is our variable of interest (Table 8).

Table 8: Relative prices per $\mathrm{kWh}$ of electricity to firewood and electricity to coal

\begin{tabular}{lrrrrr}
\hline \hline & \multicolumn{2}{c}{ Pelec/Pfirewood } & & \multicolumn{2}{c}{ Pelec/Pcoal } \\
\cline { 2 - 3 } \cline { 5 - 6 } & urban & rural & & urban & rural \\
\hline Bishkek & 0.89 & - & & 1.19 & \\
Issyk Kul & 1.25 & 1.83 & & 1.03 & 0.93 \\
Jalal-Abad & 1.15 & 1.13 & & 0.96 & 1.04 \\
Naryn & 1.20 & 1.83 & & 1.06 & 1.22 \\
Batken & 1.83 & 0.64 & & 0.74 & 0.65 \\
Osh & 1.41 & 0.82 & & 0.68 & 0.68 \\
Talas & 1.50 & 1.74 & & 0.94 & 0.96 \\
Chui & 1.62 & 1.24 & & 1.09 & 1.07 \\
\hline \hline
\end{tabular}

Note: Estimated based on KIHS (2011). Relative prices are calculated as: price of electricity (KGS/kWh) / price of fuel (KGS/kWh). The relative price is unit free. Relative price $>1$ denotes that electricity is relatively more expensive than fuel on generating one $\mathrm{kWh}$ of energy. Relative price $<1$ denotes that electricity is relatively cheaper than fuel.

\footnotetext{
${ }^{7}$ Conversion factors: $2610 \mathrm{kWh}$ per $\mathrm{m}^{3}$ of firewood, as in Silva et al. (2009); $516.72 \mathrm{kWh}$ per $100 \mathrm{~kg}$ of coal, according to http://unstats.un.org/unsd/energy/balance/conversion.htm. In the absence of a specific estimate for the Kyrgyz Republic, we adopted the lowest factor for coal conversion, cautiously assuming that residential use fuel is not of highest international standard and/or that residential stoves may not be fully efficient in extracting the highest calorific value of coal.

${ }^{8}$ When data was not available for a given region and oblast, we imputed the price values based on the most similar geographic region and oblast. Bishkek has urban areas only. Details are available upon request.
} 
Other determinants of household space heating choice are the household economic condition (log of per capita expenditure), demographic composition (household size, number of children under 16 years old, number of elderly members - above 61 years old), individual characteristics of the household head (whether the head is employed, if he has complete secondary education, and whether the household head is female), characteristics of the dwelling (ownership by the household, space area, number of rooms, whether it is a separate house or apartment in shared building), and the geographic location (urban or rural area, the terrain - high mountainous, semi-mountainous or flat, and 8 dummy variables for the regions-oblasts to control for regional effects). The summary statistics are presented in Table 9. Among the information collected by the KIHS survey, the variables included in this model represent the most comprehensive assessment of the households' characteristics. Variables which captured similar aspects of the household, as for instance accounting for the household size versus including the number of adult members, were selected to be included in the model based on the highest pairwise correlation of that variable to the space heating choice. Hence, in case of possible multicollinearity, we selected the variable which best explains variation in the choice of heating energy source. Our model specification is similar to Silva et al. (2009) and Heltberg's (2005) models of determinants of energy choice.

Table 9: Summary statistics of explanatory variables for choice of space heating energy source

\begin{tabular}{lrrrrrr}
\hline \hline Explanatory variable & All areas & Std. Dev. & Urban & Std. Dev. & Rural & Std. Dev. \\
\hline Pelec/Pfirewood & 1.21 & 0.36 & 1.29 & 0.27 & 1.18 & 0.39 \\
Pelec/Pcoal & 0.92 & 0.19 & 0.93 & 0.19 & 0.91 & 0.19 \\
Pfirewood/Pcoal & 1.34 & 0.40 & 1.49 & 0.56 & 1.29 & 0.30 \\
Per capita expenditure (KGS) & 38437.1 & 19889.5 & 39086.1 & 21126.4 & 38186.9 & 19389.6 \\
Employed members & 1.77 & 1.12 & 1.61 & 1.02 & 1.83 & 1.15 \\
Household size & 4.17 & 1.77 & 3.98 & 1.75 & 4.24 & 1.77 \\
Children under 16 & 1.42 & 1.25 & 1.29 & 1.19 & 1.48 & 1.27 \\
Elders & 0.30 & 0.57 & 0.24 & 0.53 & 0.32 & 0.59 \\
Head has secondary education* & 0.86 & 0.35 & 0.91 & 0.29 & 0.84 & 0.36 \\
Female head* & 0.33 & 0.47 & 0.35 & 0.48 & 0.33 & 0.47 \\
Own dwelling* & 0.95 & 0.21 & 0.91 & 0.28 & 0.97 & 0.17 \\
Living space area (m3) & 57.77 & 26.03 & 49.37 & 22.16 & 61.01 & 26.69 \\
Rooms & 3.47 & 1.19 & 3.23 & 1.28 & 3.56 & 1.14 \\
House* & 0.93 & 0.26 & 0.85 & 0.36 & 0.96 & 0.20 \\
Urban* & 0.28 & 0.45 & - & & - & \\
\hline \hline
\end{tabular}

Note: KIHS (2011), restricted sample. (*) dummy variables.

The model estimates by maximum-likelihood the set of coefficients, $\beta^{(1)}, \beta^{(2)}$ and $\beta^{(3)}$, for the probability of each outcome:

$$
\begin{aligned}
& \operatorname{Pr}(y=1)=\frac{e^{X \beta^{(1)}}}{e^{X \beta^{(1)}}+e^{X \beta^{(2)}}+e^{X \beta^{(3)}}} \\
& \operatorname{Pr}(y=2)=\frac{e^{X \beta^{(2)}}}{e^{X \beta^{(1)}}+e^{X \beta^{(2)}}+e^{X \beta^{(3)}}} \\
& \operatorname{Pr}(y=3)=\frac{e^{X \beta^{(3)}}}{e^{X \beta^{(1)}}+e^{X \beta^{(2)}}+e^{X \beta^{(3)}}}=1-\operatorname{Pr}(y=1)-\operatorname{Pr}(y=2)
\end{aligned}
$$

Given that the probabilities must sum to 1 , in order to identify the model one category 
is selected as baseline. We arbitrarily set $\beta^{(3)}$ as the baseline category, $\beta^{(3)}=0$. The set of coefficients $\beta^{(1)}$ and $\beta^{(2)}$ are then used to predict the fuel choice, and the probability of a household choosing each energy source becomes:

$$
\begin{aligned}
& \operatorname{Pr}(y=1)=\frac{e^{X \beta^{(1)}}}{e^{X \beta^{(1)}}+e^{X \beta^{(2)}}+1} \\
& \operatorname{Pr}(y=2)=\frac{e^{X \beta^{(2)}}}{e^{X \beta^{(1)}}+e^{X \beta^{(2)}}+1} \\
& \operatorname{Pr}(y=3)=\frac{1}{e^{X \beta^{(1)}}+e^{X \beta^{(2)}}+1}=1-\operatorname{Pr}(y=1)-\operatorname{Pr}(y=2)
\end{aligned}
$$

which can be written as the relative probabilities:

$$
\begin{aligned}
& \frac{\operatorname{Pr}(y=1)}{\operatorname{Pr}(y=3)}=e^{X \beta^{(1)}} \\
& \frac{\operatorname{Pr}(y=2)}{\operatorname{Pr}(y=3)}=e^{X \beta^{(2)}}
\end{aligned}
$$

where the individual's outcome choice $y=1$ stands for "electricity only" and outcome $y=2$ is "stove only", setting the base category $y=3$ as "combination of electricity and stove". $X$ is the set of explanatory variables.

The results estimated from the multinomial logit model refer therefore, to $\beta^{(1)}$ and $\beta^{(2)}$ coefficients in equations (3a) and (3b). The coefficients must therefore be interpreted relative to the probability of choosing the baseline outcome, i.e. in relation to the relative probability of choosing a given heating source ("electricity only" or "stove only") rather than the base category ("combination of electricity and stove"), when the explanatory variable, $X$, changes by one unit. Note, however, that in order to interpret the magnitude of the coefficients still some transformation is required. 
Table 10: Determinants of household choice of space heating source

\begin{tabular}{|c|c|c|c|c|c|c|c|c|c|c|c|c|}
\hline & \multicolumn{4}{|c|}{ all areas } & \multicolumn{4}{|c|}{ urban } & \multicolumn{4}{|c|}{ rural } \\
\hline & EL only & sd. error & ST only & sd. error & EL only & sd. error & ST only & std. error & EL only & sd. error & ST only & sd. error \\
\hline Pelectricity/Pfirewood & $-10.70 * *$ & 4.29 & $8.53 * * *$ & 1.38 & $-19.12 * *$ & 7.53 & 4.93 & 4.35 & -17.26 & 55.48 & $-55.98 * * *$ & 13.60 \\
\hline Pelectricity/Pcoal & 9.30 & 6.03 & $-13.25 * * *$ & 1.77 & $29.18 * * *$ & 10.60 & 4.30 & 5.81 & 27.92 & 66.10 & $67.83 * * *$ & 16.23 \\
\hline Pfirewood/Pcoal & $9.57 * *$ & 3.77 & $-6.95 * * *$ & 1.08 & $22.55 * * *$ & 8.67 & -3.66 & 4.97 & 16.50 & 52.57 & $53.03 * * *$ & 12.85 \\
\hline Per capita expenditure $(\ln )$ & $-0.56 *$ & 0.29 & $-0.43 * * *$ & 0.11 & $-0.77 * * *$ & 0.28 & $-0.36 * *$ & 0.16 & -0.29 & 0.67 & $-0.43 * * *$ & 0.16 \\
\hline Hh head is employed & $-0.51 * *$ & 0.24 & -0.03 & 0.09 & $-0.55 * *$ & 0.23 & $-0.41 * * *$ & 0.14 & -0.79 & 0.52 & 0.10 & 0.13 \\
\hline Head has secondary education & 0.18 & 0.35 & $-0.27 * *$ & 0.12 & 0.69 & 0.44 & $-0.47 * *$ & 0.21 & -0.22 & 0.55 & -0.24 & 0.17 \\
\hline Female head & 0.06 & 0.22 & $0.25 * * *$ & 0.09 & -0.32 & 0.22 & 0.07 & 0.13 & 0.59 & 0.47 & $0.32 * * *$ & 0.12 \\
\hline Household size & -0.11 & 0.11 & -0.02 & 0.04 & $-0.29 * * *$ & 0.10 & $-0.10 *$ & 0.05 & 0.17 & 0.23 & 0.03 & 0.05 \\
\hline Children under 16 & -0.17 & 0.13 & 0.02 & 0.05 & -0.04 & 0.12 & $0.19 * * *$ & 0.07 & -0.31 & 0.30 & -0.05 & 0.07 \\
\hline Elders & -0.29 & 0.22 & -0.04 & 0.08 & $-0.44 * *$ & 0.22 & -0.18 & 0.12 & -0.12 & 0.43 & -0.02 & 0.11 \\
\hline Own dwelling & $-0.65 *$ & 0.33 & 0.22 & 0.19 & $-0.66 * *$ & 0.29 & -0.06 & 0.24 & -0.42 & 1.08 & 0.40 & 0.30 \\
\hline Space area & 0.01 & 0.01 & $0.01 * * *$ & 0.00 & 0.01 & 0.01 & $-0.01 * * *$ & 0.00 & -0.01 & 0.02 & $0.01 * * *$ & 0.00 \\
\hline Number of rooms & $-0.36 * *$ & 0.15 & $-0.08 *$ & 0.05 & $-0.42 * * *$ & 0.14 & $0.19 * * *$ & 0.07 & 0.05 & 0.31 & $-0.15 * *$ & 0.07 \\
\hline Not living in house & $3.84 * * *$ & 0.27 & -0.31 & 0.22 & $4.16 * * *$ & 0.30 & 0.42 & 0.31 & $4.32 * * *$ & 0.63 & $-0.63 * *$ & 0.31 \\
\hline Urban & $1.85 * * *$ & 0.29 & 0.06 & 0.12 & - & & - & & - & & - & \\
\hline Terrain: semi-mountainous & 0.06 & 0.99 & $-0.83 * * *$ & 0.20 & 13.05 & 457.18 & $3.06^{* *}$ & 1.20 & -0.68 & 1.74 & $-1.11 * * *$ & 0.28 \\
\hline flat areas & 0.27 & 0.96 & $-0.49 * * *$ & 0.17 & 13.12 & 457.18 & $2.75^{* *}$ & 1.20 & -0.04 & 1.67 & $-0.63 * * *$ & 0.21 \\
\hline Region dummies (oblast) & $\mathrm{Y}$ & & $\mathrm{Y}$ & & $\mathrm{Y}$ & & $\mathrm{Y}$ & & $\mathrm{Y}$ & & $\mathrm{Y}$ & \\
\hline Constant & -0.47 & 6.04 & $16.50 * * *$ & 1.88 & -34.39 & 457.36 & -3.80 & 7.21 & -22.64 & 62.85 & $-59.39 * * *$ & 15.49 \\
\hline
\end{tabular}

Note: Restricted sample. Significant at the $* * * 1 \%, * * 5 \%$ and $* 10 \%$ significance level. The energy source combination (electricity and stove) is the base category

of dependent variable. Issyk Kul is the base category for region (oblast). High-mountainous is the base category for priz. 


\section{Results}

\subsection{The determinants of energy choice for space heating}

Table 10 reports the estimated $\beta$ coefficients in (3a) and (3b). ${ }^{9}$ The coefficients must be interpreted with regards to the direction of the expected effect on the relative probability of a specific outcome. A significant positive coefficient in electricity-only (first column in the left, center and right panels) means that a one-unit increase in the variable is associated with a greater likelihood of choosing electricity-only compared to choosing a combination of heating sources (the base outcome). In other words, a positive coefficient denotes a greater chance of moving away from using the combination electricity-and-stove towards using electricity-only. Conversely, a significant negative coefficient implies a reduced likelihood of choosing electricity-only versus choosing the base category, when the variable is increased by one unit. A coefficient that is not statistically significant is associated with having no effect on changing the relative probability of choosing a given energy source versus the base category. ${ }^{10}$

Higher household per capita expenditure is associated with a reduced probability of choosing stove-only heating versus the combination of electricity and stove. In urban areas, wealth increase is also associated with a decrease in the relative probability of choosing electricity-only versus the combination (Table 10, central panel, per capita expenditure row).

Apart from energy costs, the physical characteristics of the dwelling are also important in affecting the households' decision of choosing one source over another. First, living in urban areas is associated with a greater likelihood of choosing electricity-only over the choice of combining energy sources (Table 10, left panel, urban row). This result could be anticipated, as according to the energy consumption profile in Section 3.1 electricity-only users are concentrated in Bishkek and other urban areas.

Not living in a separate house (e.g. inhabiting dwellings in a shared building) is associated with a greater likelihood of choosing electricity-only versus a combination of electricity-and-stove heating. The effect is found both in urban and rural areas. ${ }^{11}$ However, the probability of choosing stove-only versus the combination seems to decrease in rural areas if households do not inhabit houses (if they live in apartment or dormitory in shared building).

The living space area also affects the household decision of heating source in urban and rural areas. In urban areas, one square meter increase in the living space of the dwelling is associated with a decrease in the chance of choosing stove-only versus the combination of energy sources (Table 10, central panel, area row). In rural areas, however, the effect seems to be the opposite, increasing the probability of choosing stove-only over the com-

\footnotetext{
${ }^{9}$ Caution should be placed in the rural results as the sample of rural households using electricity only is rather small.

${ }^{10}$ To interpret the magnitude of changes as relative risk ratios, however, one may need some calculation. Equations (3a) and (3b) help understand how to calculate the relative risk ratios using the results in Table 10. For example, the relative risk ratio for choosing electricity-only versus the combination of electricity and stove heating, for a one-unit increase in the variable urban (i.e. if households are not in rural, but in urban areas), is 6.359 [=exp(1.85), from Table 10, urban, second column].

${ }^{11}$ Note that within the restricted sample, households living in apartment represent 2.3 per cent of the rural sample.
} 
bination, as the space of living area increases. Controlling for area, the variable rooms captures additional heterogeneity of the effect according to the dwelling characteristics. In urban areas an additional room decreases the chance of choosing electricity-only, while it also increases the chance of choosing stove-only rather than the combination of both sources. In rural areas, one additional room is associated with a decrease in the probability of choosing stove-only, over the combination of energy sources. Ownership of the dwelling is associated with a reduced likelihood of choosing electricity-only versus the combination in urban areas, but plays no significant role in rural areas. This can be explained by the fact that over 97 per cent of rural households own their dwellings.

The type of terrain is also a key determinant for the choice of stove-only heating sources over the combination. Moving from high-mountainous to semi-mountainous terrain increases the relative probability of choosing stove-only over the combination of heating sources in urban areas. Also positive effect is found if the household is in flat ground rather than high-mountainous. The effect of terrain is however the opposite in rural areas: moving from high-mountainous terrain is associated with a move away from using stove-only, decreasing the probability of choosing this relative to the combination of electricity and solid fuels for heating.

Finally, we also control for the demographic composition of households and individual characteristics of the household head. More education of the household head is associated with a reduced chance of choosing stove-only versus the combination of electricity and stove in urban areas, although no significant effect is found in rural areas. It is interesting to note that education of the head does not affect the relative probability of choosing electricity-only over the combination choice. Having a female household head is associated with a higher probability of choosing stove-only versus the combination package in rural areas. Despite the fact that household size is in general correlated to the amount of household energy consumption, it seems not to affect the chance of choosing a particular heating source over the combination of energy sources.

\subsection{Household response to electricity price increases}

We now turn to the analysis of how an increase in electricity price could affect a move from electricity-and-stove to choosing another type of heating (Table 10, first row). An increase in the relative price of electricity to firewood $\left(P_{\text {electricity }} / P_{\text {firewood }}\right)$ is associated with reducing the chance of choosing electricity-only versus the combination electricity-and-stove heating in urban areas. Regarding the choice of stove-only versus the combination, an increase in the relative price of electricity to firewood is associated with increasing the chance of choosing stove-only, for households in general.

In line with demand theory, if electricity becomes more expensive, households would indeed tend to decrease consumption - switching off. The evidence brought by our results suggests that households would cope with higher electricity prices by also switching to alternative sources: there is evidence of a substitution effect away from the use of electricity-only in the Kyrgyz Republic, and also resilience in the use of a combination of electricity and fuels. Further investigation of changes in the composition of such an energy mix, the proportion of modern and non-modern fuels, would be a valuable addition to the literature. The environmental threat of unsustainable firewood extraction is partic- 
ularly worrisome if model predictions foresee a massive switch towards an increasing use of such fuels. As the results suggest, in the Kyrgyz Republic households seem to prefer the combination of electricity and fuel sources, or even switching to fuel-only for heating.

An interesting issue is revealed when we split the sample between urban and rural areas. An increase in the relative price of electricity to firewood is associated with a decreasing probability of choosing electricity-only over the combination in urban areas; however, such a price shock seems not to affect the relative risks of choosing electricityonly in rural areas. This could be due to the low reliability of electricity service provision in rural areas. On the other hand, a switch from the combined use of electric and stove heating towards stove-only seems unlikely in urban areas given an electricity price increase. This could be due to the fact that there are physical barriers against the use of stoves in urbanized areas, like living in an apartment. ${ }^{12}$ Results are counter intuitive for rural areas, regarding a move to stove-only.

Firewood and coal are to some extent close substitutes; both can be used in stoves for heating purposes. Nonetheless, the analysis reveals that an increase in the relative price of electricity to coal triggers different household responses than that observed for firewood. It may be useful to note that coal is a relatively expensive energy source in some regions (see Table 8). The analysis suggests that an increase in the relative price of electricity to coal is associated with an increase in the chance of choosing electricity-only versus the combination of energy sources in urban areas. This result seems at first counterintuitive. One explanation, however, is that in several urban areas electricity is still cheaper than coal (see energy per $\mathrm{kWh}$ in Table 8) and definitely cheaper than firewood (in all urban areas except Bishkek). Therefore, as long as electricity is still a cheaper source, households will tend to have less of an incentive in moving towards stove-only. In rural areas, however, an increase in the electricity price relative to coal is associated with a move towards using stove-only rather than continuing to use the combination of sources.

\section{Conclusion}

In a country like the Kyrgyz Republic with long and cold winters, having access to a reliable energy source, especially for space heating, is a basic need. While energy is relatively cheap due to high implicit subsidies for electricity and thermal power, the reliability of the electricity provision has decreased over the last decade. Power outages, especially during the winter months, are common. Below cost-recovery energy tariffs continue to hamper highly needed investments in the energy sector resulting in depleted infrastructure and poor service provision. The government, well aware of the need for reforms, undertook several (unsuccessful) attempts in the past to reform the energy sector and increase energy tariffs.

An increase in energy prices will directly affect residential consumers. Households will

\footnotetext{
${ }^{12}$ Note that these barriers may not necessarily hold in a crisis situation. In 2008, residents in Osh suffered from long blackouts following government measures to save energy. As a response, some households installed stoves in their living rooms with chimneys through the windows, despite all associated risks such as increase in carbon monoxide poisoning due to improperly installed chimneys. The UN has launched a Flash Appeal in 2008 for humanitarian support, acknowledging such episodes of poisoning (UN, 2009).
} 
either decrease their energy consumption (income effect) or switch to alternative energy sources (substitution effect). The analysis in this paper investigated the potential impact of an electricity price increase on household energy consumption. We analyzed the determinants of the choice for a particular energy source for heating and the probability that households would switch to another energy source in response to an increase in electricity prices. The findings are relevant for policy makers as a switch to alternative sources, especially if it concerns 'dirty' fuels such as firewood or coal, may carry indirect health risks due to indoor pollution. Furthermore, the depletion of firewood in local woods may have detrimental environmental effects in the long run.

In line with the findings of Silva et al. (2009) for Montenegro, we find evidence that the consumption of solid fuel, in particular firewood, in the Kyrgyz Republic would increase as response to electricity tariff increases. The analysis has shown that, overall in the country, an increase in electricity prices is associated with increasing the relative chance of households moving away from using combined electricity-and-stove sources towards using stove-only, as well as significantly lowering the chances that households would consider electricity-only versus the combination of sources. The predicted behavior regarding a switch towards alternative energy sources for space heating appears to depend on the type of fossil fuel that is currently most important, affordable or easily accessible to the household. The relative prices of firewood and coal to electricity can differ across regions and areas.

A second message drawn from the analysis is that any energy/electricity tariff increase in the Kyrgyz Republic must carefully consider the regional disparities in energy consumption. The profile of household energy consumption showed quite prominent differences across regions (oblasts), and rural versus urban areas, with regards to the energy consumption basket, energy expenditure, and likely energy quantity consumed by households. The consumption basket particularly differs among households living in different geographic terrains: households in mountainous and semi-mountainous areas are not provided with central heating, piped gas or hot water utilities, relying heavily on fuels and electricity. In spite of electricity being cheaper than fuels in several areas in the Kyrgyz Republic, and despite the fact that electricity coverage is almost universal, only 37 per cent of households use electric heating, while adoption of stoves is as high as 75 per cent of households (see Table 4). This reinforces that coverage is not a good indicator of service quality in the Kyrgyz Republic, and households have indeed recognized unreliable electricity service provision.

Profiling the households (learning more about their characteristics and the features of their dwellings) seems to be essential in order to identify areas and socio economic groups which would suffer most with an electricity price increase. Depending on the dwelling characteristics, households may have rather limited strategies for coping with a price hike. Our results confirm that households not living in a house (inhabiting apartments in shared building), for instance, face statistically significant constraints to switching to alternative sources, probably due to physical constraints of the dwellings. Other households, however, may rather respond to electricity tariff increases by easily moving towards greater use of solid fuels, such as adopting stove-only for heating purpose. This strategy could, however, decrease electricity consumption and threaten their quality of life by possibly conflicting with the achievement of other desirable development outcomes, such as good health and create disaster risks, such as landslides. 
One last note of caution on the possible general equilibrium effects: the present study does not consider possible effects of electricity price increase in other interacting markets. The results in this paper predict an increase in the demand for fossil fuels following an electricity price increase. A higher demand for fuels could, for instance, push prices up in those fuels' or other related markets. As a consequence of generalized price increase, the income effect could surmount the substitution effect and households would possibly further reduce (switch off) energy consumption. This would certainly slow down future economic development and decrease the quality of life of the Kyrgyzstani population.

\section{References}

Adenauer, I. and J. A. del Granado (2011). Burkina Faso - Policies to protect the poor from the impact of food and energy price increases. IMF Working Papers 11/202, International Monetary Fund.

Akhmetov, A. (2013). Coal industry and respiratory health assessment in Kazakhstan. Technical report, presented at ESCAS - Biennial Conference of the European Society for Central Asian Studies. Astana, Kazakhstan, August 4-7.

Duflo, E., G. M., and R. Hanna (2008). Indoor air pollution, health and economic wellbeing. Surveys and perspectives Integrating Environment and Society 1(1), available at: http://sapiens.revues.org/130\#tocfrom1n2.

EPA (-). Initiative of the World Economic Forum. Technical report, Energy Poverty Action. Available at: http://www.weforum.org/pdf/ip/energy/EPA.pdf.

Ersado, L. (2012). Poverty and distributional impact of gas price hike in Armenia. Technical report, World Bank.

Freund, C. and C. Wallich (1997). Public-sector price reforms in transition economies: Who gains? Who loses? The case of household energy prices in Poland. Economic Development and Cultural Change 46(1), 35-59.

Gassmann, F. (2013). Switching the lights off: The impact of energy tariff increases on households in the Kyrgyz Republic. Journal of Comparative Economics (in press).

Heltberg, R. (2004). Fuel switching: Evidence from eight developing countries. Energy Economics 26(5), 869-887.

Heltberg, R. (2005). Factors determining household fuel choice in Guatemala. Environment and Development Economics 10(3), 337-361.

ICG (2011). Central Asia: Decay and decline. Technical report, International Crisis Group. Asia Report No. 201. Available at: http://www.crisisgroup.org///media/Files/asia/centralasia/201\%20Central\%20Asia\%20-\%20Decay\%20and\%20Decline.pdf.

IEA, OPEC, OECD, World Bank (2010). Analysis of the scope of energy subsidies and suggestions for the G20 initiative. Technical report, Joint Report prepared for submission to the G20 Summit Meeting, Toronto, 26-27 June. Available at http://www.oecd.org/dataoecd/55/5/45575666.pdf. 
Lampietti, J. A., S. G. Banerjee, and A. Branczik (2007). People and Power: Electricity Sector Reforms and the Poor in Europe and Central Asia. The World Bank, Washington DC.

Price, C. W. and K. Pham (2009). The impact of electricity market reform on consumers. Utilities Policy 17(1), 43-48.

Silva, P., I. Klytchnikova, and D. Radevic (2009). Poverty and environmental impacts of electricity price reforms in Montenegro. Utilities Policy 17(1), $102-113$.

Slay, B. (2011). Energy and communal services in Kyrgyzstan and Tajikistan: A Poverty and Social Impact Assessment. Technical report, UNDP Bratislava Regional Centre, Bratislava.

UN (2009). Kyrgystan Flash Appeal - Revision: Humanitarian needs beyond the development interventions defined in the country development strategy. Technical report, United Nations. Available at: http://www.unocha.org/cap/appeals/revisionflash-appeal-kyrgyzstan-2009.

UNDP (2000). World Energy Assessment - Energy and the challenge of sustainability. Technical report, United Nations Development Programme.

USAID (2008). Kyrgyzstan household energy analysis and proposed social protection measures. Technical report, USAID, mimeo.

USAID (2011). Review of the prime cost of electricity. Technical report, USAID, prepared by Tetra Tech, mimeo.

World Bank (2011). Kyrgyz Republic: Profile and dynamics of poverty and inequality 2009. Technical report, The World Bank, Washington DC. 



\section{The UNU-MERIT WORKING Paper Series}

2013-01Effects of innovation on employment in Latin America by Gustavo Crespi and Ezequiel Tacsir

2013-02 Revisiting the porter hypothesis: An empirical analysis of green innovation for the Netherlands George van Leeuwen and Pierre Mohnen

2013-03 Impact of external knowledge acquisition strategies on innovation - A comparative study based on Dutch and Swiss panel data by Spyros Arvanitis, Boris Lokshin, Pierre Mohnen and Martin Wörter

2013-04 Interactive knowledge exchanges under complex social relations: A simulation modelRobin by Cowan and Anant Kamath

2013-05 Innovation systems framework: still useful in the new global context? by Michiko lizuka

2013-06 The importance of intrinsic and extrinsic motivation for measuring IQ by Lex Borghans, Huub Meijers and Bas ter Weel

2013-07 Firms' innovation capability-building paths and the nature of changes in learning mechanisms: Multiple case-study evidence from an emerging economy by Paulo N. Figueiredo, Marcela Cohen and Saulo Gomes

2013-08 A set of time series data labour market stocks and flows for the Netherlands 1980 to 2010 by Manuel Müllers, Joan Muysken and Erik de Regt

2013-09 Designing an optimal 'tech fix' path to global climate stability: R\&D in a multiphase climate policy framework by Adriaan van Zon and Paul A. David

2013-10 Complementarity between internal knowledge creation and external knowledge sourcing in developing countries by Jun Hou and Pierre Mohnen

2013-11Summarizing large spatial datasets: Spatial principal components and spatial canonical correlation by Samyukta Bhupathiraju, Bart Verspagen and Thomas Ziesemer

2013-12 Regional systems of innovation in the Arab region by Samia Satti Osman Mohamed Nour

2013-13 Development and social justice: Education, training and health in Sudan by Samia Satti Osman Mohamed Nour

2013-14 The economic importance and impacts of intellectual property rights (IPRs) in Sudan by Samia Satti Osman Mohamed Nour

2013-15 Overview of knowledge economy in the Arab region by Samia Satti Osman Mohamed Nour

2013-16 The importance (impacts) of knowledge at the macro-micro levels in the Arab Gulf countries by Samia Satti Osman Mohamed Nour

2013-17 Political determinants and impact analysis of using a cable system as a complement to an urban transport system by Diego Escobar-García, Francisco García-Orozco and Carlos Cadena-Gaitán

2013-18 Women entrepreneurs in the informal economy: Is formalization the only solution for business sustainability? By Shyama V. Ramani, Ajay Thutupalli, Tamas Medovarszki, Sutapa Chattopadhyay, Veena Ravichandran

2013-19 Heterogeneity in innovation strategies, evolving consumer preferences and market structure: An evolutionary multi-agent based modelling approach by Salih Çevikarslan 
2013-20 Optimal patent length and patent breadth in an R\&D driven market with evolving consumer preferences: An evolutionary multi-agent based modelling approach by Salih Çevikarslan

2013-21 Innovation and productivity: An update by Pierre Mohnen and Bronwyn H. Hall 2013-22 Fathers' use of parental leave. What do we know? by Nevena Zhelyazkova

2013-23 Eliciting Illegal migration rates through list randomization by David McKenzie and Melissa Siegel

2013-24 How do ICT firms in Turkey manage innovation? Diversity in expertise versus diversity in markets by Semih Akçomak, Erdal Akdeve and Derya Fındık

2013-25 Dynamic models of R\&D, innovation and productivity: Panel data evidence for Dutch and French manufacturing by Wladimir Raymond, Jacques Mairesse, Pierre Mohnen and Franz Palm

2013-26 Centre-based versus home-based childcare by Robert Bauchmüller

2013-27 Microeconometric evidence of financing frictions and innovative activity by Amaresh K Tiwari, Pierre Mohnen, Franz C Palm and Sybrand Schim van der Loeff

2013-28 Innovation for economic performance: The case of Latin American firms by Elena Arias Ortiz, Gustavo Crespi, Ezequiel Tacsir, Fernando Vargas and Pluvia Zuñiga

2013-29 Is money all? Financing versus knowledge and demand constraints to innovation Gabriele Pellegrino and Maria Savona

2013-30 Child deprivation in Ontario - A (less than perfect) comparison with Europe by Geranda Notten

2013-31 Measuring performance: does the assessment depend on the poverty proxy? by Geranda Notten

2013-32 How big is the impact of infrastructure on trade? Evidence from meta-analysis by Mehmet Güney Celbis, Peter Nijkamp and Jacques Poot

2013-33 Using a 'Systems' Perspective to Explain the Limits of 'New' Multinational Enterprises: the role of 'members-only' location advantages by Rajneesh Narula

2013-34 Foreign direct investment as a driver of industrial development: why is there so little evidence? by Rajneesh Narula

2013-35 The end of the multifibre arrangement (MFA) and the heterogeneous performance of quota-constrained countries by Mulu Gebreeyesus

2013-36 Techological capability building in MNE-related social businesses of less developed countries: The experience of Grameen-Danone Foods in Bangladesh by Jahan A. Peerally and Paulo N. Figueiredo

2013-37 The links between economic integration and remittances behaviour of migrants in the Netherlands by Özge Bilgili

2013-38 The influence of vulnerability on migration intentions in Afghanistan by Craig Loschmann and Melissa Siegel

2013-39 How unemployment insurance savings accounts affect employment duration: Evidence from Chile by Paula Nagler

2013-40 Self-organization of knowledge economies by François Lafond

2013-41 Designing an optimal 'tech fix' path to global climate stability: Directed R\&D and embodied technical change in a multi-phase framework by Adriaan van Zon \& Paul A. David

2013-42 The growth of outward FDI and the competitiveness of the underlying economy: the case of India by Rajneesh Narula and Tiju Prasad Kodiyat 
2013-43 The impact of migration on children left behind in Moldova by Franziska Gassmann, Melissa Siegel, Michaella Vanore and Jennifer Waidler

2013-44 Technological spillovers and industrial growth in Chinese regions by Lili Wang, Huub Meijers and Adam Szirmai

2013-45 Male use of parental leave in Luxembourg: Empirical analysis of administrative records by Nevena Zhelyazkova

2013-46 Exploring the paradox of competence-creating subsidiaries: balancing bandwidth and dispersion in MNEs by Rajneesh Narula

2013-47 Switching off or switching source: energy consumption and household response to higher energy prices in the Kyrgyz Republic by Franziska Gassmann and Raquel Tsukada 